\title{
ベクター産生型骨髄間質細胞を利用した遺伝子治療
}

\author{
岡田尚巳
}

\section{Gene Therapy with Vector-producing Multipotent Mesenchymal Stromal Cells}

\author{
Takashi OKADA \\ Department of Molecular Therapy, National Institute of Neuroscience, National Center of Neurology and \\ Psychiatry, 4-1-1 Ogawa-Higashi-cho, Kodaira, Tokyo 187-8502, Japan
}

(Received July 20, 2010)

\begin{abstract}
Suicide gene therapy with retroviral vector-producing cells was feasible as an adjuvant to the surgical resection of recurrent glioblastoma, although any benefit appeared to be marginal. Further evaluation of the therapeutic strategy with the vector-producing cells must incorporate improved delivery of vectors and transgenes to the target cells. We have previously demonstrated the ability of vector-producing tumor cells engineered by the adenovirus-retrovirus hybrid vector to destroy satellite tumor cells, although therapeutic efficacy for aggressive tumor has to be further evaluated by the systemic delivery of the vector-producing cells. Mesenchymal stem cells (MSCs) should be an effective delivery vehicle to seek out tumor cells in vivo and transport cancer-killing gene or immune products with minimal rejection reaction by the host. We developed vector-producing tumor-tracking cells to improve suicide cancer gene therapy. Nucleofection was attempted to deliver retrovirus vector components into rodent MSCs. Athymic nude mice with subcutaneous 9L glioma were received vector-producing MSCs through the left ventricular cavity. Optical bioluminescence imaging in vivo revealed accumulation of the MSCs into the subcutaneous 9L tumors but not Rat-1 transplants. Consequently, the vectorproducing MSCs significantly enhanced pro-drug killing of glioma cells compared to MSCs without ability to generate progeny virus. Our study demonstrated the effective MSCs-mediated tumor transduction with progeny vector production to improve suicide gene therapy. Although therapeutic benefit in the various orthotopic or metastatic tumor models has to be further validated, this transduction strategy would eradicate evasive tumors in situ.
\end{abstract}

Key words — mesenchymal stem cell; gene therapy; virus vector

\section{1.はじめに}

がんに対し様々な遺伝子治療の臨床試験が行われ ているが，いまだ十分な臨床的効果は得られていな い. 現行法では，遺伝子導入に様々なウイルスベク ターが用いられているが, 腫瘍標的が可能で遺伝子 導入効率が高いシステムが確立されていない。この ため, 安全で臨床的に有効な新規遺伝子導入系の開 発が急務である。

遺伝子治療としては，血管新生抑制や抗腫瘍免疫 誘導等，様々なストラテジーが提案されているが, 直接的に腫瘍の細胞死を誘導する方法として自殺遺 伝子療法が開発された。この自殺遺伝子治療では,

国立精神・神経医療研究センター神経研究所遺伝子疾 患治療研究部（下187-8551 東京都小平市小川東町 41-1)

e-mail: t-okada@ncnp.go.jp

本総説は, 日本薬学会第 130 年会シンポジウムS19 で 発表したものを中心に記述したものである.
導入遺伝子が発現していない周辺のがん細胞も死ぬ というバイスタンダー効果を伴うことから高い治療 効果が期待され，欧米を中心に臨床試験が実施され た. ${ }^{1 ）}$ 使用する自殺遺伝子としては様々なものが提 唱されたが，Herpes simplex virus thymidine kinase gene (HSV-tk) と代謝拮抗剤 ganciclovir (GCV) を組み合わせた自殺遺伝子治療が最も広く検討され てきた．神経膠腫に対しては，レトロウイルス産生 細胞を腫瘍組織内に移植する治療方法が開発され,

NIH の Oldfield 博士及び Blaese 博士らのグループ が，定位脳装置を用いて脳腫瘍内に HSV- $t k$ 遺伝子 を発現するレトロウイルスベクターの産生細胞を移 植した。この細胞は持続的にウイルスを産生し，周 囲の腫瘍細胞に感染して HSV- $t k$ 遺伝子を組込む働 きをする.ところが，ウイルス産生細胞はマウス由 来の線維芽細胞を改変したものであったことから移 植後に拒絶され易く，組織内での拡散や治療遺伝子 
の導入効率が不十分であった，ただし，極めて低い 遺伝子導入効率にもかかわらず抗腫瘍効果が認めら れた症例があったことは，HSV-tk 遺伝子のバイス タンダー効果による強力な殺細胞現象が生体内で生 じた結果であると考えられる。また，腫瘍内に新生 した異常血管の内皮細胞が障害されることもバイス タンダー効果の一因と考えられており，血管新生を 抑制する手法を組み合わせることにより，さらに効 果的に腫瘍退縮を試みることも有望と思われる。こ のため，遺伝子送達方法を中心とした基盤技術開発 の重要性が高まっている.

治療遺伝子の改良として, HSV- $t k$ 遺伝子の作用 を増強した変異型 HSV- $t k$ 遺伝子も応用が検討され ている.さらに，同様の自殺遺伝子治療として，

Escherichia coli cytosine deaminase (CD) 遺伝子に よる 5-Fluorocytosine (5-FC) から 5-Fluorouracil (5-FU) への活性化, thymidine phosphorylase $(t p)$ と 5'-deoxy-5-fluorouridine（DFUR）との組み合わ せ，そして cytochrome P450 遺伝子による cyclophosphamide（CPA）の活性化等の方法がある.

さらに自殺遺伝子治療の効果を高めるため，宿主 の感染細胞に対する免疫応答を併用したワクチン治 療, ${ }^{2)}$ 遺伝子増幅システム, ${ }^{3)}$ ヒストン脱アセチル化 酵素阻害剂の併用4)など，様々な技術の開発が推進 されているが，ウイルスに対する免疫応答を制御す る技術の実用化も今後の重要な課題である.

\section{2. 治療遺伝子の増幅}

がんに対する遺伝子治療を成功させるためには, 治療遺伝子を目的の病巣に効率よく選択的に導入 し，さらにその後も安定に発現させることが重要で ある。このために多くのウイルスが遺伝子を運ぶべ クターとして応用されてきたが，どのウイルスも理 想的なべクターとは言い難い。従来から用いられて いるべクター系の短所を克服するためには，免疫抑 制プロトコールの改善のほか，中和抗体の影響を受 け難いべクター，感染標的分子，遺伝子発現増強剂 や遺伝子増幅法の開発が望まれる。

高い遺伝子導入効率をもたらす新規のベクター系 としては，複数のベクター系を組み合わせて短所を 相互に補完するハイブリッドベクターが有用と考え られる。われわれは，ハイブリッドベクターを用い て子孫ベクターを腫瘍内で分泌させ，治療遺伝子を 局所で増幅させるシステムを開発した. ${ }^{3)}$ アデノウ

イルスベクターは，体内の様々な細胞に感染し遺伝 子発現が可能であるが，免疫原性が比較的強く，発 現は一過性であり，急速に減弱する，また，アデノ ウイルスはウイルス自身の DNA を標的細胞のゲノ ムに組込む確率が $10^{-5}$ 程度と極めて低いため，外 来遺伝子の発現は細胞分裂により急激に減衰する. これに対し，レトロウイルスはウイルスゲノムが標 的細胞の染色体に組込まれるため長期の発現が可能 だが，分裂中の細胞にしか感染しない。この両者の 欠点を補うために，アデノウイルスを骨格とするべ クターにレトロウイルスのゲノムを搭載したハイブ リッドのベクターを構築した。両者を組み合わせた ハイブリッドベクターは，初期感染においてはアデ ノウイルスの感染機構を用いて静止期の腫瘍細胞に も感染し，腫瘍内で子孫レトロウイルスを産生す る。 その後，子孫ウイルスは最初の段階で感染でき なかった周囲の細胞にも感染し，高い効率で遺伝子 導入が可能となる。レトロウイルスの性質を利用し て遺伝子は染色体に組込まれ長期間の発現を示す。 このような複数のウイルスの特徵を生かし各々の欠 点を解消したハイブリッドウイルスベクターは，ウ イルスの生物学的特徴をうまく利用した新規のベク ターとして応用が期待される.

ハイブリッドベクターを用いた自殺遺伝子治療の 効果を検証するため，われわれは，HSV-tk又は EGFP を発現するハイブリッドベクター (Ad.LTR EGFP，Ad.LTR.TK）を構築し，がんにおける治 療効果を検証した（Fig.1）。安全のため，自己複製 型ウイルスが生じ難いように，複数のベクターを用 いて発現させる手法を用いた。 また，従来のハイブ リッドベクターでは，パッケージングベクターから の env の発現によって細胞の env 受容体が飽和して しまい，ウイルスが感染し難くなるという問題があ った。 そこで，この問題を解決するために，過剩発 現でも飽和し難く多くの腫瘍組織に親和性が高い VSV-G を用いたシュードタイプベクターを利用し

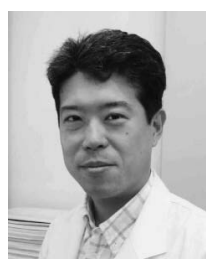

岡田尚已
国立精神・神経医療研究センター 神経 研究所 遺伝子疾患治療研究部 遺伝子治 療技術開発室長. 1991 年金沢大学医学 部卒業. 1995 年金沢大学大学院医学研 究科修了. 1996 年米国 NIH 客員研究 員. 2000 年自治医科大学助手. 2004 年 講師。2007 年現職. 専門は脳神経外 科, 遺伝子治療基盤技術の開発. 


\section{Therapeutic vectors}

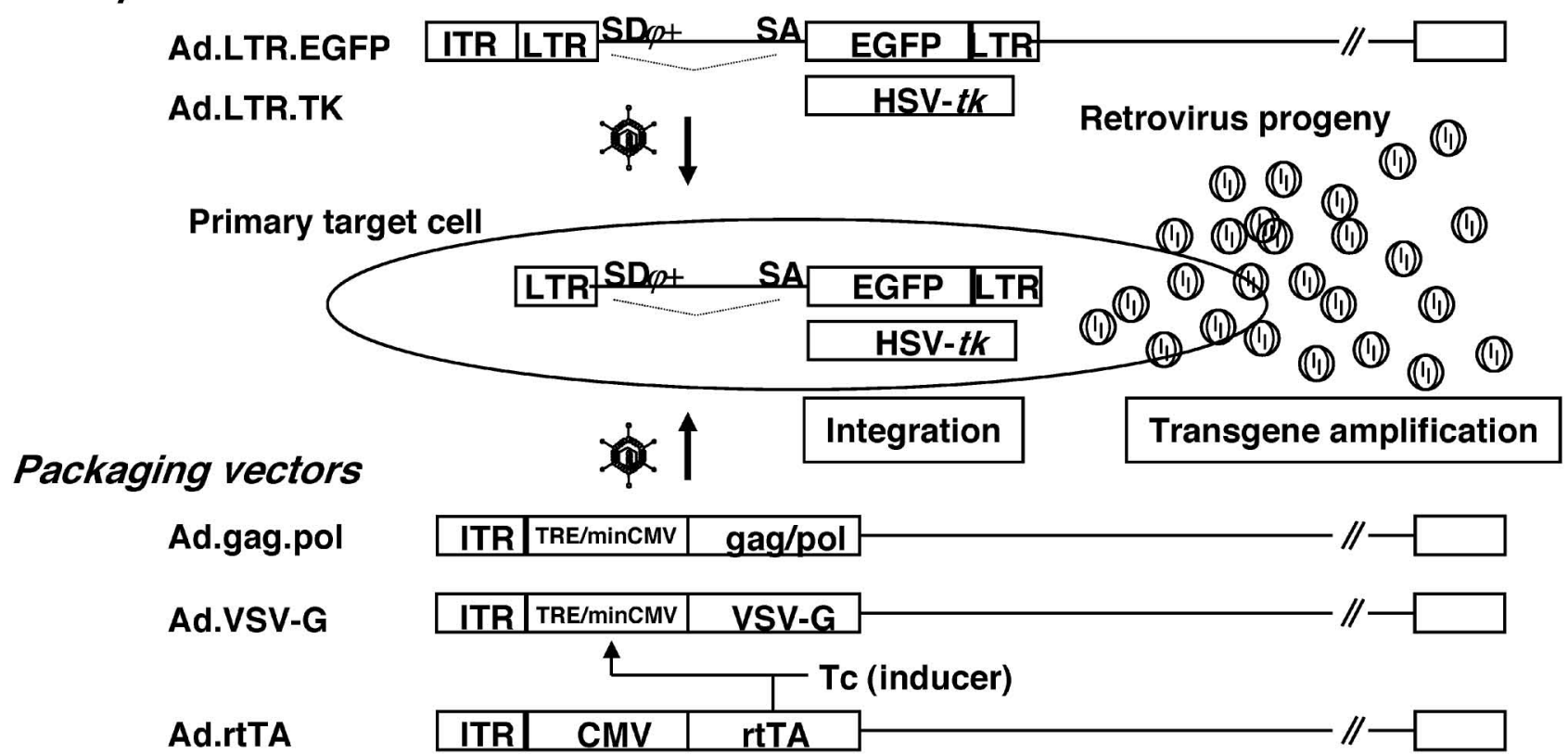

Fig. 1. In Situ Transduction of Target Cells with Trans-complementing Hybrid Adeno-retroviral Vectors

The adeno-retroviral hybrid vector containing the retroviral vector genome was constructed (Ad.LTR.EGFP or Ad.LTR.TK) . Co-transduction of primary target cells with adeno-retroviral hybrid vector together with vectors expressing packaging proteins of retroviruses (Ad.gag.pol, Ad.VSV-G) as well as an inducer (Ad.rtTA) could integrate and amplify the transgene in situ.

た.Ad.LTR.EGFP とパッケージングベクターを 腫瘍細胞に混合感染させてレトロウイルスベクター を誘導すると，非誘導時に比べて EGFP 陽性細胞 の割合が増加した。また，治療ベクターとして Ad.LTR.TK を用いてパッケージングベクターとと もに腫瘍細胞に混合感染させると，がん細胞のガン シクロビル（GCV）に対する感受性が増強した。 さらに，ヌードマウス皮下腫瘍に Ad.LTR.TK とパ ッケージングベクターを混合感染させ，治療遺伝子 の発現増強と GCV 投与後の抗腫瘍効果の増強を確 認した。この際に GCV を投与しなかった群の皮下 腫瘍から DNA を抽出し，定量的 PCR 法にて治療 遺伝子のコピー数を調べてみると，レトロウイルス の誘導条件下で 200 倍弱の増幅が確認された．現在 さらに，ヒトには病原性がないアデノ随伴ウイルス （AAV）を複製するシステムを開発中である。ま た，未分化な腫瘍細胞における遺伝子導入効率を上 げる感染標的アダプター分子5) や遺伝子発現増強 剤4)などの併用により，ハイブリッドベクターの遺 伝子導入効率をさらに改善することが可能であると 考えられる。これらのシステムを応用することによ り, 臨床的効果の高い治療遺伝子増幅法の実用化が 期待される．アデノウイルスは比較的広範囲の組織
に感染し大きな遺伝子の挿入が可能であることか ら，ハイブリッドベクターの基本骨格として利用さ れている場合が多いが，Herpes simplex virus(HSV)， Epstein-Barr virus（EBV），ポックスウイルス，ア ルファウイルスやワクシニアウイルスなど，様々な ウイルスを利用したハイブリッドベクターやアンプ リコンシステムが開発されている.

3. 間葉系幹細胞と腫瘍との相互作用

間葉系幹細胞（MSCs）は，骨，軟骨，脂肪，筋 肉，血管，神経など様々な組織へと分化する広範囲 の多分化能力を有している。近年，炎症部位や組織 傷害部位への集積性と免疫抑制作用が注目され，こ の性質を利用し，欧米で GVHD（graft versus host disease，移植片対宿主拒絶反応）治療への臨床応用 が活発化してきている. ${ }^{6)}$ MSCs は HLA が一致し なくても使用可能で倫理的な障壁が低く，わが国で も臨床治験の準備が進行中である.

炎症部位への MSCs の集積には，各種のケモカ インの関与が示唆されているが，がんは，“neverhealing wounds”と言われるように絶えず炎症を伴

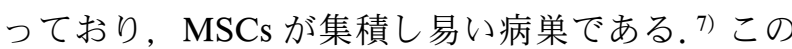
集積性を利用して，転移・浸潤性の高い腫瘍を標的 として全身投与による臨床的な効果が期待される. 
さらにMSCs には血液脳関門の透過性があること も報告されており, ${ }^{8)}$ 脳腫瘍の治療にも有用と考え られる，MSCs は，骨䯣や脂肪のほか，胎児肝臓， 肺，羊水，胎盤，臍帯血，月経血など様々な組織か ら調製可能であるが，マーカーや性質は若干異なる ことが知られている。中でも骨髄液は，比較的容易 に繰り返し採取することができるため，移植用 MSCs のソースとして有望である。しかし MSCs は 骨髄液中で全細胞の数十万個に 1 個程度しか存在せ ず，また細胞寿命も線維芽細胞などと比較して短 い.このため，自家 MSCs による再生医療を普及 させるためには，これらを大量に培養して増幅する 技術が重要である。われわれは，CD271 陽性 MSCs が高い増殖能を示し，かつ多分化能力を保持 していることを確認している（Kasahara et al., 投 稿準備中)。さらに実用化に向け，実際に患者に移 植する前に, 細胞の品質を短期間に高い精度で確認 する技術の開発が望まれる。

ただし，MSCsの安全性が完全に確立されたわけ ではない，また，腫瘍細胞と MSCs との相互作用 により，腫瘍の増殖能や転移能に様々な変化が生じ る可能性も指摘されている，乳がん細胞を用いた検 証では，腫瘍細胞の増殖能には大きな変化はないも のの，MSCs ががん細胞の転移能を一過性に促進す るという可能性が指摘された. ${ }^{9)}$ 腫瘍細胞との相互 作用によって MSCs からのケモカイン（CCL5）の 産生が誘導された結果，腫瘍細胞の走化性が刺激さ れたことが示唆されている。ささらに，MSCsから分 泌される Ang1（angiopoietin-1），VEGF（vascular endothelial growth factor) や PDGF (platelet-derived growth factor) などの因子が相乗的に作用し, 血管新生を促すという可能性も指摘された。ただ し，相互作用の影響は腫瘍の種類により大きく異な り，その作用機序や安全性との係わりについては, 今後の詳細な解析を待たなければならない。

\section{4. がん治療への応用}

MSCs の腫瘍への集積性を利用し，遺伝子修飾 MSCs を利用した様々ながん治療が考えられる，集 積能のある細胞を用いるメリットとして，全身的投 与によって転移巣も含めた治療が可能であること や，治療タンパク質の濃度を局所的に高くすること で多臓器への悪影響を回避させる効果が期待できる ことが挙げられる，動物モデルでは，免疫療法とし
て IFN- $\beta^{10)} や \mathrm{IL}-12^{11)}$ を発現する遺伝子修飾 MSCs の抗腫瘍効果が報告された。同様に，NK4 を用い て血管新生を抑制する取り組みも提案されてい

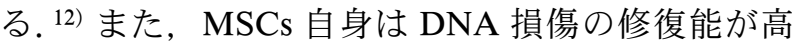
く放射線照射にも抵抗性が高いという性質があり， $\mathrm{CD}$ 発現 MSCs を利用した自殺遺伝子治療のモデル が報告されている. ${ }^{13)}$

MSCs を利用したこれらの治療方法の効果を改善 させるためには，標的組織内で感染を維持させる工 夫や集積能をさらに高める技術が有用と考えられ る. 腫瘍内でウイルスを増殖させ，ウイルス自身の 腫瘍細胞毒性を利用する手法として，MSCs を担体 として制限増殖型ウイルスを腫瘍に送達させる試み が報告されている. ${ }^{14)}$ ただし，治療遺伝子を効果的 に発現させ，臨床的有効性を得るためには，MSCs への細胞傷害性が低くかつ遺伝子発現を安定に維持 するシステムが望まれる。

全身投与による腫瘍組織への集積後に，生着細胞 の周辺で効果的な治療遺伝子の発現を得るためには,

MSCs を土台としたウイルス産生細胞が有用である と期待される. ${ }^{15)}$ 従来の遺伝子修飾細胞の場合，移 植後の生着効率が低いため，細胞を移植しても，十 分量の遺伝子発現を長期間維持することは困難であ る [Fig. 2(A)]。これに対して，腫瘍組織内でベク ターを産生し続けるウイルス産生細胞を利用した場 合には，長期間続く高い遺伝子導入効率が期待され る [Fig. 2(B)]。また，腫瘍内のがん幹細胞の維持 にMSCs が支持細胞として重要な役割を果たして いることからも，MSCs 自身に治療遺伝子発現べク 夕一を産生させることは治療に有利である。われわ れは，ベクター産生型 MSCs を用いたがんに対す る新しい細胞治療戦略を提案し（特許出願中），治 療遺伝子の増幅と病巣イメージングを行い，自殺遺 伝子治療への応用の可能性を検証した。 ${ }^{16)} \mathrm{Lu}-$ ciferase 発現レトロウイルスベクタープラスミド, gag-pol 発現プラスミド及び VSV-G 発現プラスミ ドを，Nucleofection 法にて SD ラット骨髄由来 MSCs に導入後，経時的に培養上清を採取し，ウイ ルス産生量の推移を解析した。また，MSCsへの遺 伝子導入 24 時間後, 皮下に $9 \mathrm{~L}$ 細胞を接種した ヌードマウスの左心室腔内に遺伝子導入細胞を注入 し，生体イメージング装置を用いて腫瘍での遺伝子 発現を経時的に評価した。その結果，遺伝子導入 
A

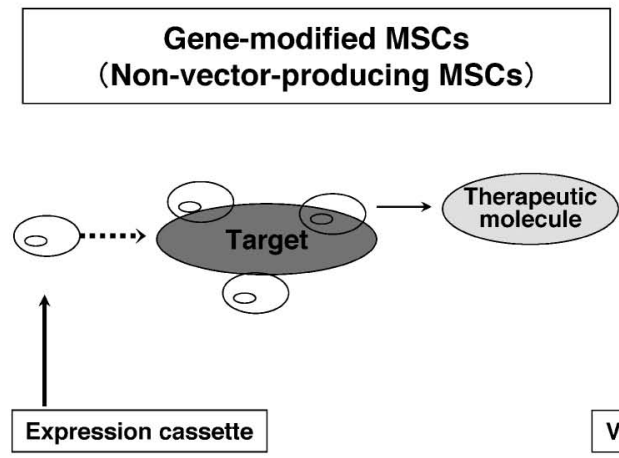

Transient expression

B

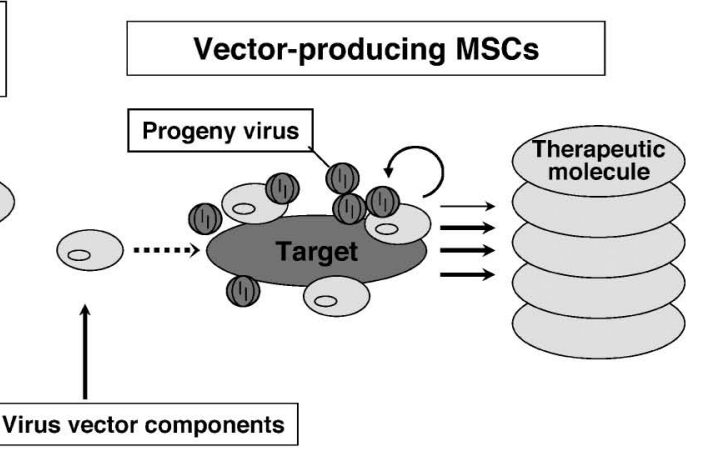

Long-term extensive expression

Fig. 2. Improved in Situ Vector Production Strategy

A. Gene-modified MSCs: Although gene-modified MSCs have tumor-seeking property, local expression of the therapeutic protein is up to the presence of the MSCs. B. Vector-producing MSCs: Progeny virus produced by the MSCs can transduce target cells in situ to amplify the therapeutic genes, which would be followed by long-term extensive expression, even when MSCs fade away.

24 時間後より，間葉系幹細胞からベクターが分泌 されることが確認された。さらに，全身投与された MSCs は皮下腫瘍に集積し，ベクター分泌にて遺伝 子発現を増幅していることが示唆された．本遺伝子 増幅システムによって，生体内でのがん病巣の検出 と治療遺伝子の増幅が可能であり，診断や治療への 応用が期待される.

\section{5. 将来展望}

がん遺伝子治療に必要な遺伝子導入技術にはまだ まだ改善の余地が多く, 基礎研究の重要性が再認識 されている，遺伝子治療の実用化に向けて，様々な ベクター系を用いた遺伝子導入が行われているが, いずれのべクター系にも短所がある。このため，こ れまでに蓄積されてきた膨大な知見を活用し，新た な遺伝子導入技術の開発を推進することが必要であ る. 臨床試験での反省を生かした次世代の遺伝子導 入技術が次々と考案されており，より優れた治療方 法の開発に向けて基礎技術は着実に進歩している. 腫瘍の生物学的な特性を考慮したべクターの開発が さらに進めば，より幅広い治療方法の選択が可能と なり，適応症例も広がることが期待される．臨床研 究では日本は欧米諸国に遅れをとっているが，歴史 的にはまだ遺伝子治療は始まったばかりであり，日 本独自の技術を応用した臨床試験の成果が今後期待 される。

MSCs をべクター産生細胞として用いるがん治療 戦略として, 自殺遺伝子治療以外にも, 免疫療法や
血管新生抑制療法による全身的治療への応用が期待 される. MSCs の腫瘍集積性とべクター産生に伴う 遺伝子増幅効果をうまく利用し，従来の遺伝子治療 の臨床的効果を大きく改善することが望まれる，将 来の臨床応用に向け，高い安全性と有効性を担保す るためには，腫瘍細胞との相互作用を様々なモデル で解析するとともに，集積能と特異性の向上が重要 な課題である。また，MSCs が産生する子孫べク ターとして, 安全性の高い AAV ベクターの応用も 期待される。分泌型のレトロウイルスと異なり, AAV を産生させ組織内で拡散させるためには工夫 を要するが，感染細胞の染色体には組込まれ難いた め，全身投与した場合の長期的な安全性を鑑みる場 合，極めて有用な担体である，治療遺伝子の発現に 関しては，ベクター系の工夫に合わせて，併用薬剤 としてヒストン脱アセチル化酵素阻害剤を用いた治 療遺伝子発現増強法が有効と考えられる。アデノウ イルスベクターの場合には，増強効果の作用機序と して受容体の発現誘導が知られており，ベクタ一感 染前に薬剂を投与することが有効である。これに対 して AAVベクターにおいては，ベクターゲノムが 感染直後からヒストン修飾を受け脱アセチル化を受 けていることから，AAVベクターの感染に合わせ て投与すると高い効果が期待できる. ${ }^{4)}$

MSCs を用いた治療法は現時点では確立されたも のとは言いがたいが，今後，様々なストラテジーで 臨床試験が推進されることにより，臨床効果と安全 
面での課題が次第に明らかになっていくものと思わ

れる，従来のベクター系の短所を補完するべクター 産生型 MSCs の応用により, 様々な腫瘍に対し標 的化遺伝子増幅を利用した新たな治療法が開発され ることが期待される.

\section{REFERENCES}

1) Ram Z., Culver K. W., Oshiro E. M., Viola J. J., DeVroom H. L., Otto E., Long Z., Chiang Y., McGarrity G. J., Muul L. M., Katz D., Blaese R. M., Oldfield E. H., Nat. Med., 3, 1354-1361 (1997).

2) Okada T., Shah M., Higginbotham J. N., Li Q., Wildner O., Walbridge S., Oldfield E., Blaese R. M., Ramsey W. J., Gene Ther., 8, 1315-1322. (2001).

3) Okada T., Caplen N. J., Ramsey W. J., Onodera M., Shimazaki K., Nomoto T., Ajalli R., Wildner O., Morris J., Kume A., Hamada H., Blaese R. M., Ozawa K., J. Gene Med., 6, 288-299 (2004)

4) Okada T., Uchibori R., Iwata-Okada M., Takahashi M., Nomoto T., Nonaka-Sarukawa M., Ito T., Liu Y., Mizukami H., Kume A., Kobayashi E., Ozawa K., Mol. Ther., 13, 738-746 (2006).

5) Ito A., Okada T., Mizuguchi H., Hayakawa T., Mizukami H., Kume A., Takatoku M., Komatsu N., Hanazono Y., Ozawa K., J. Gene Med., 5, 929-940 (2003).

6) Le Blanc K., Rasmusson I., Sundberg B., Gotherstrom C., Hassan M., Uzunel M., Ringden O., Lancet, 363, 1439-1441 (2004).

7) Lazennec G., Jorgensen C., Stem Cells, 26, 1387-1394 (2008).

8) Nakamizo A., Marini F., Amano T., Khan A.,
Studeny M., Gumin J., Chen J., Hentschel S., Vecil G., Dembinski J., Andreeff M., Lang F. F., Cancer Res., 65, 3307-3318 (2005).

9) Karnoub A. E., Dash A. B., Vo A. P., Sullivan A., Brooks M. W., Bell G. W., Richardson A. L., Polyak K., Tubo R., Weinberg R. A., Nature, 449, 557-563 (2007).

10) Studeny M., Marini F. C., Champlin R. E., Zompetta C., Fidler I. J., Andreeff M., Cancer Res., 62, 3603-3608 (2002).

11) Chen X. C., Wang R., Zhao X., Wei Y. Q., Hu M., Wang Y. S., Zhang X. W., Zhang R., Zhang L., Yao B., Wang L., Jia Y. Q., Zeng T. T., Yang J. L., Tian L., Kan B., Lin X. J., Lei S., Deng H. X., Wen Y. J., Mao Y. Q., Li J., Carcinogenesis, 27, 2434-2441 (2006).

12) Kanehira M., Xin H., Hoshino K., Maemondo M., Mizuguchi H., Hayakawa T., Matsumoto K., Nakamura T., Nukiwa T., Saijo Y., Cancer Gene Ther., 14, 894-903 (2007).

13) Kucerova L., Altanerova V., Matuskova M., Tyciakova S., Altaner C., Cancer Res., 67, 6304-6313 (2007).

14) Stoff-Khalili M. A., Rivera A. A., Mathis J. M., Banerjee N. S., Moon A. S., Hess A., Rocconi R. P., Numnum T. M., Everts M., Chow L. T., Douglas J. T., Siegal G. P., Zhu Z. B., Bender H. G., Dall P., Stoff A., Pereboeva L., Curiel D. T., Breast Cancer Res. Treat., 105, 157-167 (2007).

15) Okada T., Ozawa K., Front. Biosci., 13, 18871891 (2008).

16) Uchibori R., Okada T., Ito T., Urabe M., Mizukami H., Kume A., Ozawa K., J. Gene Med., 11, 373-381 (2009). 